\title{
Efficacy of Online Education during nCOVID- 19 pandemic lockdown among Medical and Allied Health Students in India
}

Manna Debnath ( $\square$ mannadebnath93@gmail.com )

Charotar University of Science and Technology https://orcid.org/0000-0002-2874-5464

\section{Santosh Ojha}

Charotar University of Science and Technology

Anupam Niraula

Charotar University of Science and Technology

Dolly Sharma

Charotar University of Science and Technology

\section{Research Article}

Keywords: Pandemic Lockdown, Online Education, COVID-19, Healthcare

Posted Date: March 1st, 2021

DOI: https://doi.org/10.21203/rs.3.rs-251322/v1

License: (a) (i) This work is licensed under a Creative Commons Attribution 4.0 International License.

Read Full License 


\section{Abstract}

The outbreak of COVID-19 has caused sensation and fear among the world population. World Health Organization (WHO) announced the COVID-19 outbreak as a pandemic on the 11th of March 2020 and India was one of the first countries to initiate the national pandemic lockdown. The teaching and learning process has been greatly impacted by this decisive step taken by the Government of India. Thereafter many institutes in India have adopted the online mode for the continuation of the teaching-learning process. A standard questionnaire was prepared and circulated among all participants within India via the online platform. A total of 1042 participants submitted their responses out of which $53 \%$ were females and $47 \%$ were males. $77 \%$ of students stated that they have attended online classes conducted by their respective educational institutes. The majority of the students were very much interested in online education (via Google platform, Zoom, etc.) but the practical knowledge was not adequate. Online education can be a good method of learning and improving the overall academic progress but it might not be as effective as a traditional education system for improving the practical aspect of learning in the case of the Medical and Allied Health students during the lockdown.

\section{Background}

The Novel coronavirus is one of the lethal viruses with high transmission. In December 2019, the first Coronavirus case was reported in Wuhan City. After 2-3 weeks of COVID-19 outbreaks, Covid cases were reported in the United States, Europe, and many Asian countries [1]. According to the World Health Organization (WHO), the virus responsible for nCOVID-19 is severe acute respiratory syndrome coronavirus 2 (SARS-CoV-2) [2]. The patients of Coronavirus disease were reported with various symptoms like fever, running nose, cough, sneezing, headache, body ache, sore throat, diarrhoea, respiratory distress, and pneumonia. The WHO declared the serious situation a public health emergency internationally on 30th January 2020 and hollar for a collaborative effort of entire countries to the widespread of this Coronavirus [3-4]. India, the largest democratic country was also on high alert due to COVID-19. On 24th March 2020, India took the historical decision of a 21-days complete lockdown effective from 25th March till 14th of August. Due to the continuing rapid spread of the Coronavirus, the Government of India has decided to extend the lockdown from the 15th of April to 3rd May, furthermore extended it from 4th May to 17th May. During these 54-days of complete lockdown in India, the growth rate of new cases had gradually reduced and the recovery rate was much higher than in other countries [5].

During this pandemic lockdown, all the universities and colleges were closed and the teaching-learning process was severely disrupted. However, continuing the educational process by effective use of technology was very important for students to continue their learning process. Considering the limitations of the lockdown the Ministry of Human Resource Development (MHRD) and the University Grants Commission (UGC) suggested continuing with the teaching-learning process using online modes such as Google classroom, Google Hangout, Cisco Webex Meeting, Youtube Streaming, OERs, SWAYAM Platform, and SWAYAMPRABHA, etc. The faculty members have contributed a lot for the benefit of students during 
the lockdown period by using many tools like WhatsApp groups, emails, and other social media applications [6].

In this present study, we have performed a survey on ongoing remote education practice and its effectiveness in different universities and colleges in India during the COVID-19 lockdown.

\section{Methods}

A web-based survey study was conducted during the national lockdown period between 29th April to 4th May 2020. A standard questionnaire was prepared in the Google form and was forwarded to teaching faculties of different universities and institutes for the collection of data. The institutional ethical board was not accessible due to the pandemic lockdown, so telephone approval was obtained from the Charotar Healthcare and Research Foundation (CHRF) University Hospital, Changa, Gujarat.

The questionnaire consisted of two parts: The demographic part and Online Education Questionnaire. The demographic variables include Gender, Age, Department, and State. The questionnaire had 5 questions [Table:2], 4 questions were regarding the overall status of academic progress during the lockdown, and 1 question was regarding the mode of online platform used for academics during the lockdown. The participants were informed about the objectives of the study and informed consent was taken by answering a close-end question 'Yes' or 'No' to confirm the willingness to participate voluntarily. After taking the informed consent participants were directed to submit the self-administered questionnaire. The anonymity and confidentiality of all the data collected from the participants were maintained throughout the study.

\section{Statistical Analysis}

The analysis of the data was done by using descriptive statistics of mean and standard deviation. Data Analysis was performed by using IBM SPSS Statistics for Windows, version 20.0 (IBM Corp., Armonk, N.Y., USA).

\section{Results}

A total of 1042 students from various disciplines of medical and paramedical professions participated in the survey study. Among which $482(47 \%)$ were males and 560 (53\%) were females having the mean age of $21.19 \pm 3.20$ years and $20.40 \pm 2.28$ years respectively.

The samples of the study were collected from different states of India by using Google forms and the majority of them were from Gujarat, West Bengal, and Tripura [Figure: 1].

Students from different departments of Medical and Allied health sciences showed good responses during the collection of samples. The majority of the students participated from the department of 
Medical Imaging Technology (49\%), Medical Laboratory Technology (19\%), Operation Theatre and Anesthesia Technology (8\%), and Nursing (7\%) [Figure: 2].

Table 1

Table showing the response of participants regarding the academic progress, experience of the online class, and practical knowledge improved among the students who have attended the online classes.

\begin{tabular}{|c|c|c|c|c|c|}
\hline \multirow{3}{*}{$\begin{array}{l}\text { Overall progress of all participants } \\
\text { (1042 students) }\end{array}$} & \multicolumn{5}{|c|}{ Academic progress during the lockdown } \\
\hline & Poor & Unsatisfactory & Average & Good & Excellent \\
\hline & $98(9 \%)$ & $110(11 \%)$ & $\begin{array}{l}386 \\
(37 \%)\end{array}$ & $\begin{array}{l}264 \\
(25 \%)\end{array}$ & $\begin{array}{l}184 \\
(18 \%)\end{array}$ \\
\hline \multirow{6}{*}{$\begin{array}{l}\text { Online classes conducted by } \\
\text { Institution ( } 797 \text { Students i.e., } 77 \% \text { of } \\
\text { students attended online classes) }\end{array}$} & \multicolumn{5}{|c|}{ Experience of online classes over regular classes } \\
\hline & Poor & Unsatisfactory & Average & Good & Excellent \\
\hline & $81(10 \%)$ & $119(15 \%)$ & $\begin{array}{l}234 \\
(29 \%)\end{array}$ & $\begin{array}{l}227 \\
(29 \%)\end{array}$ & $\begin{array}{l}136 \\
(17 \%)\end{array}$ \\
\hline & \multicolumn{5}{|c|}{$\begin{array}{l}\text { Percentage of practical knowledge improved during Online } \\
\text { Classes }\end{array}$} \\
\hline & $\begin{array}{l}\text { Strongly } \\
\text { Disagree }\end{array}$ & Disagree & Neutral & Agree & $\begin{array}{l}\text { Strongly } \\
\text { Agree }\end{array}$ \\
\hline & $\begin{array}{l}146 \\
(18 \%)\end{array}$ & $152(20 \%)$ & $\begin{array}{l}209 \\
(26 \%)\end{array}$ & $\begin{array}{l}176 \\
(22 \%)\end{array}$ & $\begin{array}{l}114 \\
(14 \%)\end{array}$ \\
\hline
\end{tabular}

The response of participants to question regarding overall progress was highest for average progress i.e., 386 students (37\%) followed by 264 students $(25 \%)$ had good progress, $184(18 \%)$ students reported excellent academic progress, $110(11 \%)$ students have reported unsatisfactory and 98 (9\%) students revealed poor academic progress during lockdown [Table: 1].

The majority of the Medical and allied health students have reported that their institution has actively engaged with students for Online classes like taking lectures, submission of assignments, and case report presentations in Google platform and Zoom application. Approximately $77 \%$ of students stated that the online class was conducted by their institutions in India whereas $23 \%$ of students revealed that there were no online classes taken during lockdown by their institution.

Most of the universities and colleges used the Google platform (like Google classroom, Google duo, etc) (419 students i.e., 52.6\%) as their principal application for online classes followed by Zoom application (267 students i.e., $33.5 \%$ ), Others (106 students i.e., 13.3\%) and Edmodo application (5 students i.e., $0.6 \%$ ) [Figure: 3].

\section{Discussion}


A macro-level study was conducted by United Nations Educational, Scientific and Cultural Organization (UNESCO), the United Nations Children's Fund (UNICEF), and the World Bank to assess the National Education Responses to COVID-19 School Closures, among which India was also one of the countries to respond to the survey [12]. To the best of our knowledge, this is the first study conducted at the microlevel from a student's perspective to evaluate the academic progress of online education for Undergraduate students during the lockdown in India.

A total of 1042 students from 15 departments in various States and Union Territories of India participated in this survey study. In this pandemic situation, majority of the medical and paramedical institute has changed their pedagogy to remote education in the mid-semester and started sending e-content, various online webinar, online case report, and assignment submission to their students to gain knowledge. The present study showed that out of 1042 participants approximately $77 \%$ of participants responded that their institution has organized the online classes, as for the rest $23 \%$ of participants didn't attend any online classes. According to the study, all the medical and allied health students are very interested in an online class as compared to the conventional methods.

In April 2019, Saurabh R Shrivastava and Prateek S Shrivastava performed a study based on E-learning in Medical Education and Strategies to counter them in which they reported that the major challenges of online education are the lack of resource person available. Many institutes have faced challenges regarding hardware, software, and poorly skilled technical staff as a result of this it becomes challenging for online medical and allied health learning [7]. In June 2018 O'Doherty D et al, conducted a study based on online learning in medical education in that they mentioned that online learning can provide easier and wider variety and a greater quantity of information. They also reported that the development of online education and the implementation of online learning method among medical faculties and students will be better prepared for the challenges faced in this digital age [8]. Vaona A et al, in January 2018 performed a study based on the e-learning of health professionals in which they reported that e-learning could be more successful than traditional learning in particular medical education settings [9]. In the present study, the majority of the students reported that online classes are more useful and enjoyable than conventional classes. Online training seminars through video programs and live interaction were also conducted. Apart from online classes, the students were undergoing regular online counseling for psychological and mental support, and daily follow up of their academic progress were taken. Healthcare students also need practical exposure but during the lockdown period, the facilities to improve the practical knowledge were not accessible by all the universities and institutes in India. These facilities include the use of the virtual simulation laboratory for a demonstration of the medical procedures. The students are not getting adequate practical learning exposure as they need during the pandemic lockdown but when it comes to the overall academic progress the response of the students is altogether good and the majority of the participants are using the Google platform (52.57\%) for online education in India.

Recently, UGC has already announced to reopen the universities but due to the COVID-19 situation, regular classes are not started yet in many of the teaching institutes. Despite the nCOVID situation, the students 
should have practical exposure along with the ongoing online classes. The virtual simulation laboratory can be an ideal method of learning to facilitate practical knowledge.

\section{Limitation}

There may be potential sample bias in this analysis, as the selection of samples was unequal for all departments and all the states of India. Further research with a detailed questionnaire and equal sampling for all the departments can be conducted to overcome these limitations of the present study.

\section{Conclusion}

The Global Study conducted by United Nations Educational, Scientific and Cultural Organization (UNESCO), the United Nations Children's Fund (UNICEF), and the World Bank concluded that remote learning was adapted by school level which included online education and TV/Radio Broadcast [12]. The present study performed on Undergraduate students reveals that the majority of the students in India have attended online classes conducted by their respective institutions. The overall academic progress among all medical and allied health students is good but the practical knowledge seems stagnant. To improve online practical exposure to the student's virtual simulation laboratory set up can be done to improve their practical knowledge [10-11].

\section{Annexure}

Table 2

Questionnaire of Online Education during nCOVID- 19 pandemic lockdown

\section{Questions}

Q1. Are online classes being conducted by your institution?

Q2. According to you are online lectures sufficient enough to improve your practical knowledge.

Q3. Rate your experience of online classes over regular classes.

Q4. Mode of online platform used for conducting online classes/Assignments submission/case report presentation.

Q5. Rate your academic progress during the national lockdown period?

\section{Options}

Yes, No

Strongly Disagree, Disagree, Neutral, Agree, Strongly Agree

Poor, Unsatisfactory, Average, Good, Excellent

Google platform, Zoom, Edmodo, Others

Poor, Unsatisfactory, Average, Good, Excellent

\section{References}

1. Israil Review on Novel Corona Virus (nCOVID or COVID-19): Worldwide Pandemic. Available at SSRN 3566747. 2020 Apr 2. http://dx.doi.org/10.2139/ssrn.3566747 
2. Li Y, Xia L. Coronavirus disease 2019 (COVID-19): role of chest CT in diagnosis and management. American Journal of Roentgenology. 2020 Feb 21:1-7. org/10.2214/AJR.20.22954

3. Kooraki S, Hosseiny M, Myers L, Gholamrezanezhad A. Coronavirus (COVID-19) outbreak: what the department of radiology should know. Journal of the American college of radiology. 2020 Feb 19. https://doi.org/10.1016/j.jacr.2020.02.008

4. Zhong BL, Luo W, Li HM, Zhang QQ, Liu XG, Li WT, Li Y. Knowledge, attitudes, and practices towards COVID-19 among Chinese residents during the rapid rise period of the COVID-19 outbreak: a quick online cross-sectional survey. International Journal of Biological Sciences. 2020;16(10):1745. doi: $7150 /$ ijbs.45221

5. Ray D, Salvatore M, Bhattacharyya R, Wang L, Mohammed S, Purkayastha S, Halder A, Rix A, Barker $D$, Kleinsasser $M$, Zhou Y. Predictions, role of interventions and effects of a historic national lockdown in India's response to the COVID-19 pandemic: data science call to arms. medRxiv. 2020 Jan 1. https://doi.org/10.1101/2020.04.15.20067256

6. UGC Guidelines on Examinations and Academic Calendar for the Universities in View of COVID-19 Pandemic and Subsequent Lockdown.2020 April 29: 2-

11.https://www.ugc.ac.in/pdfnews/4276446_UGC-Guidelines-on-Examinations-and-AcademicCalendar.pdf

7. Shrivastava SR, Shrivastava PS. Challenges Associated With the Introduction of E-learning in Medical Education and Strategies to Counter Them. MAMC Journal of Medical Sciences. 2019 Jan 1;5(1):43. DOI: 10.4103/mamcjms.mamcjms_17_19

8. O'Doherty D, Dromey M, Lougheed J, Hannigan A, Last J, McGrath D. Barriers and solutions to online learning in medical education-an integrative review. BMC medical education. 2018 Dec;18(1):130. https://doi.org/10.1186/s12909-018-1240-0

9. Vaona A, Banzi R, Kwag KH, Rigon G, Cereda D, Pecoraro V, Tramacere I, Moja L. E-learning for health professionals. Cochrane Database of Systematic Reviews. 2018(1).

https://doi.org/10.1002/14651858.CD011736.pub2

10. Dikshit A, Wu D, Wu C, Zhao W. An online interactive simulation system for medical imaging education. Computerized Medical Imaging and Graphics. 2005 Sep 1;29(6):395-404. https://doi.org/10.1016/j.compmedimag.2005.02.001

11. Al-Elq AH. Simulation-based medical teaching and learning. Journal of family and Community Medicine. 2010 Jan;17(1):35. doi: 4103/1319-1683.68787.

12. UNESCO Institute for Statistics (UIS), based on UNESCO-UNICEF-World Bank Survey on National Education. Responses to COVID-19 School Closures, 1st Iteration. 2020. http://tcg.uis.unesco.org/survey-education-covid-school-closures

\section{Figures}




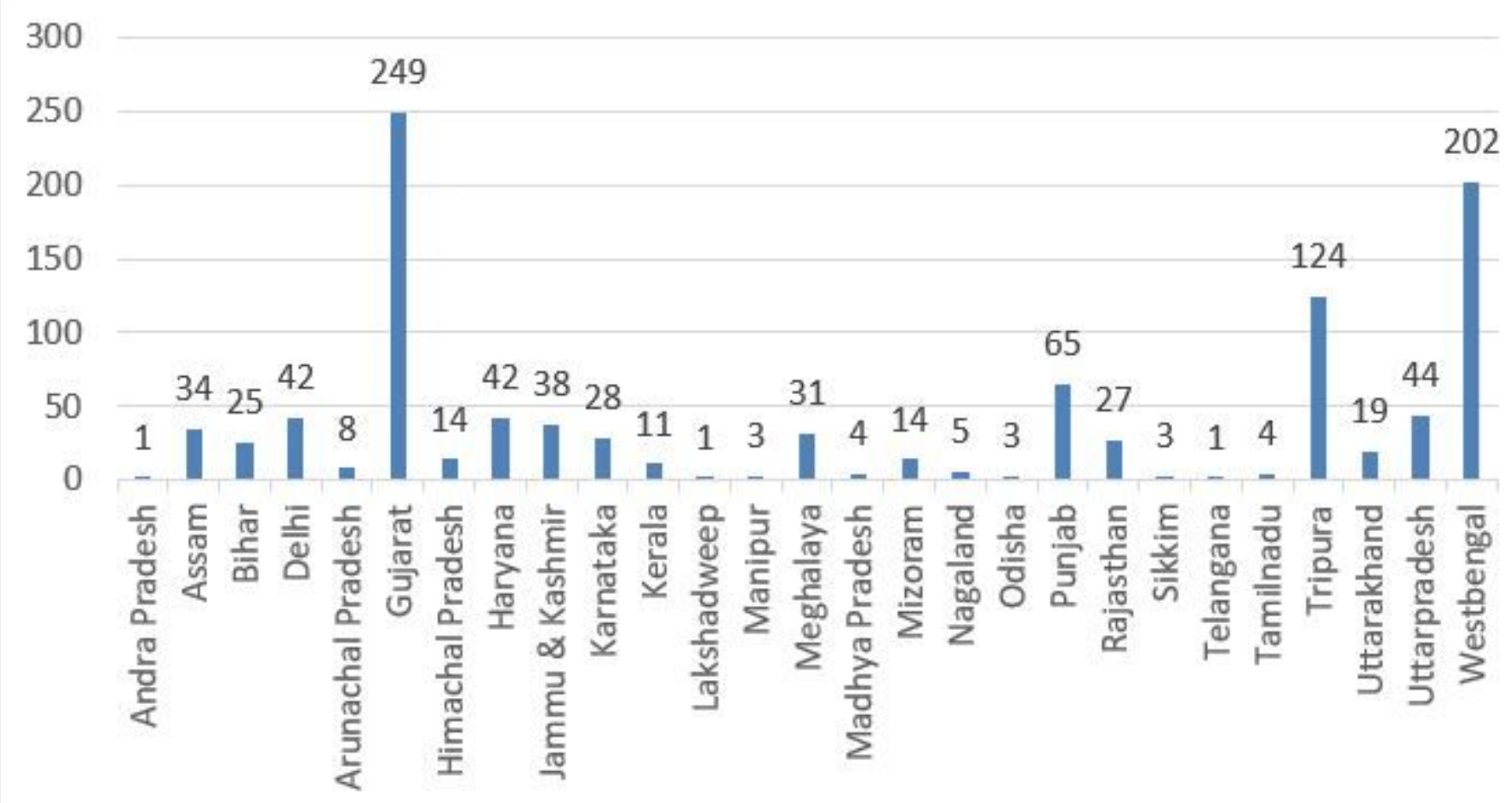

\section{Figure 1}

Distribution of Students who participated from different states of India

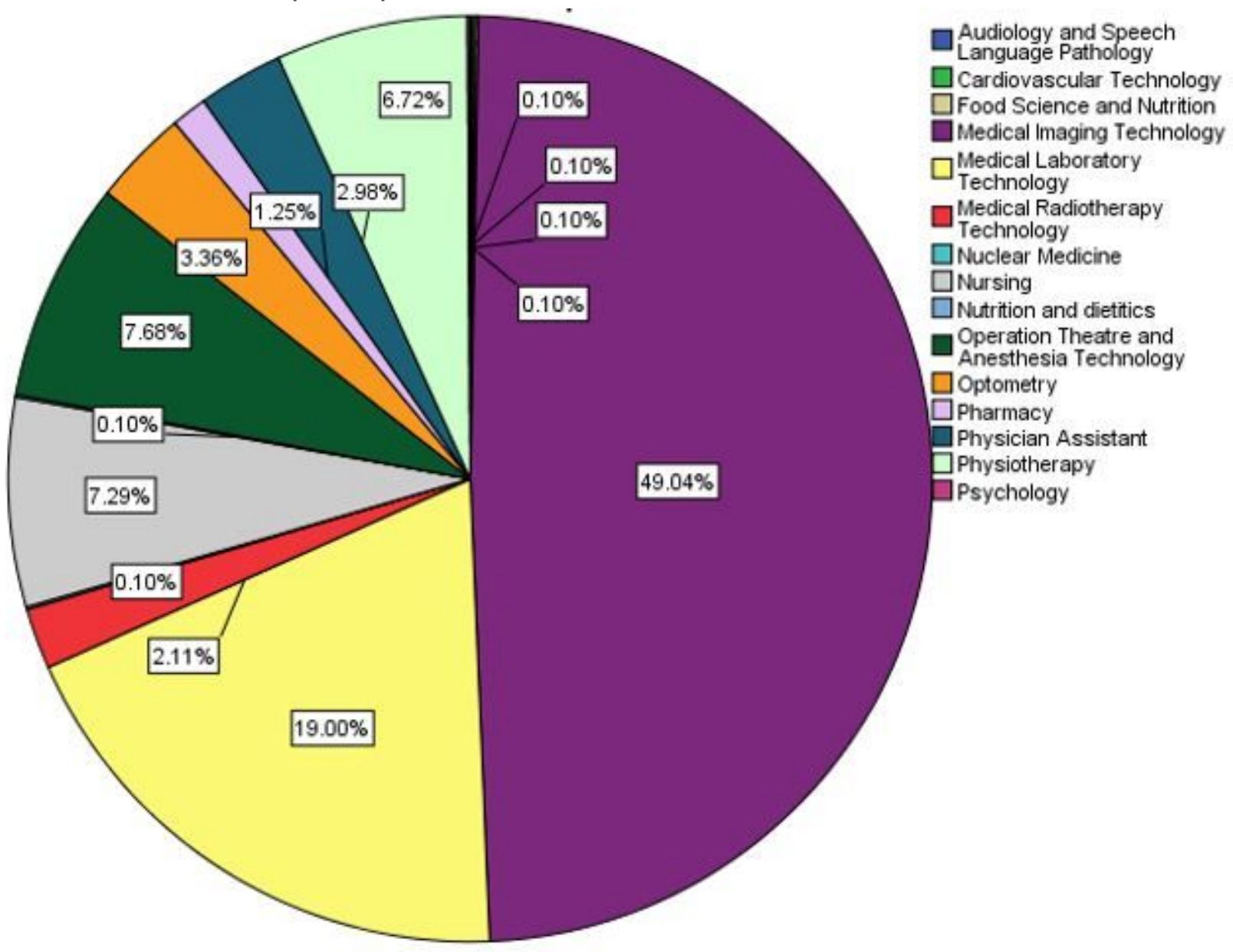


Figure 2

Pie chart showing the percentage of students that participated from different branches of Medical and Allied Health Science

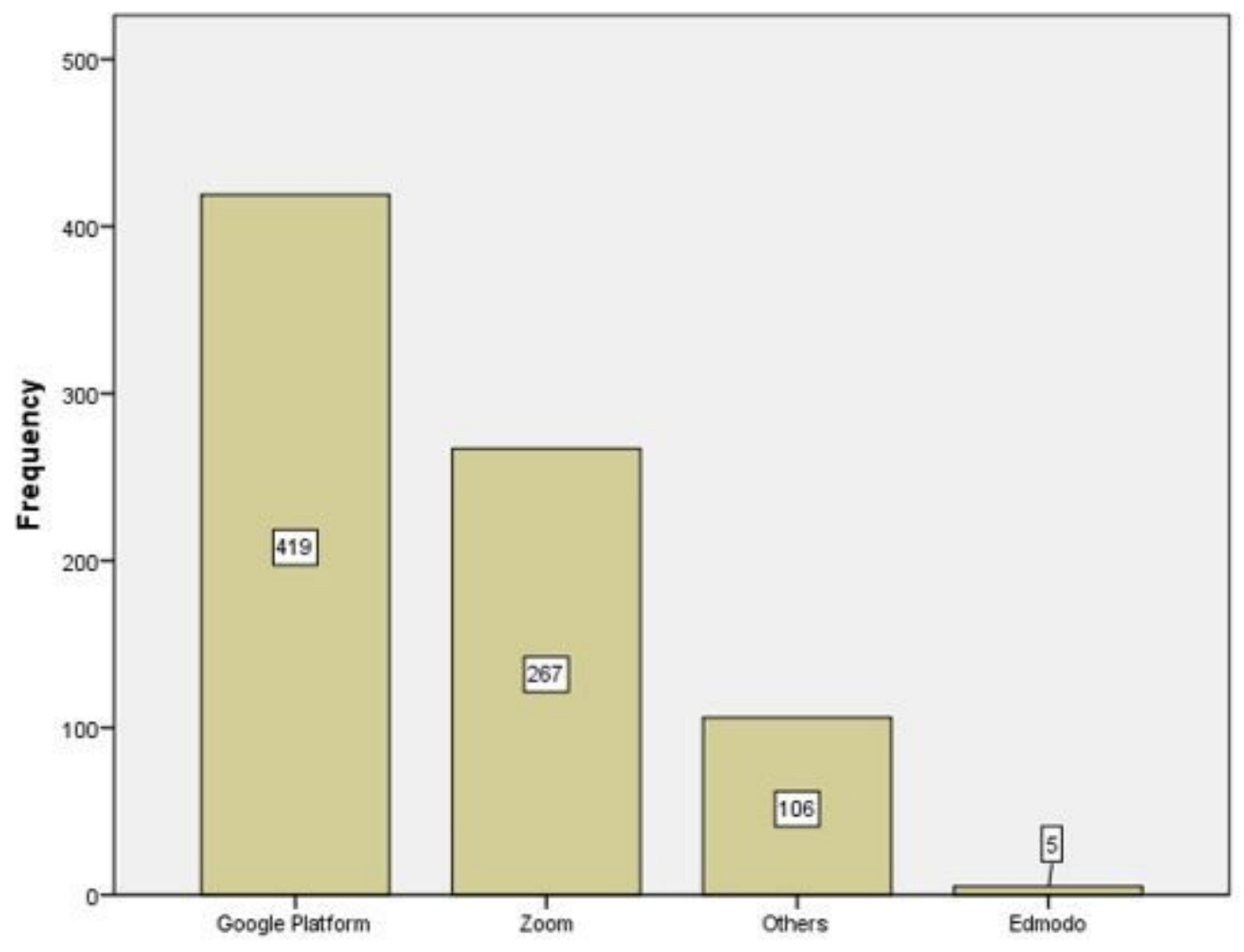

Figure 3

Online platform used by students for Remote learning 